\title{
Biological Quality of Fresh Water Snail of Fermented (Pomacea canaliculata and Pomacea glauca) The Using Different Additivies
}

\author{
Siti Dharmawati \\ Islamic University Of Kalimantan \\ Banjarmasin \\ South Kalimantan, Indonesia \\ dharmauniska@gmail.com
}

\author{
Nordiansyah Firahmi \\ Islamic University Of Kalimantan \\ Banjarmasin \\ South Kalimantan, Indonesia \\ didi_uniska@yahoo.com
}

\begin{abstract}
Research has been aim to evaluated the effect of processing "kalambuai" swamp on nutrient composition. This study used an experimental method $(2 \times 4 \times 5)$ factorial by the uses 240 male alabio ducks to designed which was repeated 5 times where each experimental unit consisted of 12 male Alabio ducks aged 2 months. The first factor is the species snails (Pomacea glauca and Pomacea canaliculata) and the second factor is the processing process (steamed, biological silage, acidic and tepsil silage). The results showed that the biological silage processing method gave the best results and improved nutrient composition, protein efficiency ratio, metabolic energy, protein digestibility, amino acid composition and amino acid digestibility.
\end{abstract}

Keywords-biologically quality, fresh water snail, fermented, different additives

\section{INTRODUCTION}

Feed cost was largest component of total production cost of poultry han 81 to $88 \%$ (Dharmawati, 2014). The high price of feed rations due to animal protein sources as one of the composed ration comes from imported materials such as fwash meal are often used in poultry diets. The feed costs can be reduced by arranging the feed itself by making use of local feed ingredients. One of the local feed ingredients that can be used were fresh water snail.

The fresh water snail has been chosen as a source of animal protein rations because the fresh water snail protein content was equivalent to fwash meal which was $57.43 \%$ (Dharmawati, 2006). The fresh water snails contain complete nutrients, but still have the disssadvantage of us, Pomacea glauca species containing tannin $692 \mathrm{mg} / 100 \mathrm{~g}$ and sulfuric acid found in mucus. Furthermore, from Udoh's (1994) report on golden snail, there were tannin $592 \mathrm{mg} /$ $100 \mathrm{~g}$, oxalic acid $381 \mathrm{mg} / 100 \mathrm{~g}$ and hidrosianin acid 112 mg / 100 g. These substances affect poultry performance, especially Alabio ducks if given in fresh or raw form. In addition to the presence of anti-nutritional in mucus, the body structure of fresh snails was a good place for parasites to proliferate. These parasites are trematode larvae in the form of ingested embryos, which are easy to grow and proliferate in the body twassues of freshwater snails. In addition, freshwater snails have the ability to absorb pesticides in rice fields so that it was quite dangerous if have given directly to livestock. To eliminate thwas, processing needs to be done. The Processed could be affect the nutrient content found in fresh water snails, especially proteins, amino acids and vitamins. So that the proper processing method was needed to obtain processed products that contain high nutrient values.

Some indicators used to determine the quality of feed ingredients can be seen from nutrient content, metabolizable energy value, protein and amino acid digestibility, protein use efficiency and Nitrogen retention. In general, feed ingredients are said to have good quality if they have a balanced nutrient composition and can livestock responded, so that if applied to the ration, it was expected to improve the efficiency of ration use and improve the performance of the livestock.

Snail silage preserved biologically ensiling usually uses corn or cassava as a source of carbohydrates. But given corn, tapioca and cassava are a food that was also used by humans, it was necessary to look for other alternatives to utilize carbohydrate sources that do not compete with humans such as rice bran and onggok. The use of rice bran and onggok are the two materials that are potentially used as a source of carbohydrates in the processing of "Kalambuai" fresh water snails silage considering its availability was quite large.

\section{METHODS}

\section{A. Experimental and Design}

The main ingredients used are (1) snail species (Pomacea glauca or kalambuai) and (Pomacea canaliculata or golden snails / mulberry) which are processed in the form of steam, biological silage, silage acid and tepsil (2) male Alabio ducks aged $5 \pm 0.5$ months. The number of colony cages used was 40 units, each measuring 50x100x50 cm, each of which was occupied by 12 ducks.

\section{Kalambuai Flour Making Procedure}

In the study will be used raw fresh water snail which was processed through steaming, biological silage (ensiling), acid silage and tepsil.

\section{Determination of Metabolizable Energy}

\section{RESULT AND DISCUSSION}

\section{A. Freshwater snail 'Kalambuai'Nutrient Content}

The fresh water as Pomacea glauca species contains higher protein, fat and phosphorus than the Pomacea 
canaliculata species and contains lower crude crude fiber and calcium. According to Maynard (1985), the content of nutrient composition of a product was influenced by species and processing methods. The high content of protein, fat and snail phosphorus in the Pomacea glauca species compared to Pomacea canaliculata was thought to be closely related to the nutritional composition of the two snail species before processing. The results of the study by Dharmawati (2004) showed that in the fresh form the nutrient content of the snail species of Pomacea glauca was higher (Protein $48.75 \%$, fat $3.45 \%$, crude crude fiber $4.77 \%$, Calsium $3.26 \%$ and phosphorus $0.16 \%$ ) higher than the species Pomacea canaliculata (Protein $28.45 \%$, fat $1.45 \%$, crude crude fiber $15.45 \%$, Calsium $15.24 \%$ and phosphorus $0.13 \%$ ). In line with the research of Suwarni (1988) and Riani $(1990,1992)$ of freshwater snails (snails) that the content of protein, fat and phosphorus (As feed) was relatively low at $15.58 \%, 0.70 \%$ fat and $0.13 \%$ phosphorus while the content of crude crude fiber and calcium was relatively high at $22.30 \%$ and $29.33 \%$, respectively.

Protein content of freshwater snail "kalambuai" which was processed by the biological silage method was higher than the other three treatments. The high protein content was found in the freshwater snail of the Pomacea glauca species treated with biological silage method (61.64\%) whereas the acid silage containing $52.06 \%$ crude protein. The results of thwas study contain higher protein than the study Novianti et al (2012) which has cilated the snail with $3 \%$ formic acid and $15 \%$ BAL turned out to contain $10.88 \%$ protein up to $14.54 \%$.

\section{TABLE 1. THE COMPOSITION NUTRIENT OF FRESH WATER SNAIL SILAGE TREATED WITH DIFFERENT} METHODS

\begin{tabular}{|c|c|c|c|c|c|c|}
\hline \multirow{2}{*}{ Species } & \multirow{2}{*}{ Processing } & \multicolumn{5}{|c|}{ Kandungan Nutrient (\%) } \\
\hline & & Protein & Fat & Crude fiber & Calsium & Phosporus \\
\hline \multirow{4}{*}{ P. Glauca } & Steamed & $49.85^{\mathrm{a}}$ & $1.84^{\mathrm{b}}$ & $3.65^{\mathrm{d}}$ & $2.79^{\mathrm{e}}$ & $0.27^{\mathrm{e}}$ \\
\hline & Silage acid & $49.99^{\mathrm{a}}$ & $3.49^{\mathrm{e}}$ & $1.76^{\mathrm{b}}$ & $2.41^{\mathrm{d}}$ & $0.21^{\mathrm{c}}$ \\
\hline & Silage Biologi & $61.64^{\mathrm{e}}$ & $2.76^{\mathrm{d}}$ & $4.19 \mathrm{e}$ & $2.13^{\mathrm{c}}$ & $1.19^{\mathrm{g}}$ \\
\hline & Tepsil & $53.70^{\mathrm{c}}$ & $2.10 b^{c}$ & $0.94^{\mathrm{a}}$ & $1.61^{\mathrm{b}}$ & $1.61^{\mathrm{f}}$ \\
\hline \multirow{4}{*}{ P. Canaliculata } & Steamed & $50.91^{\mathrm{a}}$ & $2.61^{\mathrm{d}}$ & $3.70^{\mathrm{d}}$ & $3.11^{\mathrm{f}}$ & $0.19^{\mathrm{b}}$ \\
\hline & Silage acid & $52.06^{\mathrm{b}}$ & $2.43^{\mathrm{cd}}$ & $2.48^{\mathrm{c}}$ & $2.62^{\mathrm{e}}$ & $0.24^{\mathrm{d}}$ \\
\hline & Silage Biologi & $57.78^{\mathrm{d}}$ & $2.23^{\mathrm{b}}$ & $3.57^{\mathrm{d}}$ & $2.37^{\mathrm{d}}$ & $0.24^{\mathrm{d}}$ \\
\hline & Tepsil & $57.28^{\mathrm{d}}$ & $1.27^{\mathrm{a}}$ & $3.62^{\mathrm{d}}$ & $1.62^{\mathrm{a}}$ & $0.16^{\mathrm{a}}$ \\
\hline
\end{tabular}

${ }^{\text {abcdefg }}$ mean value within rows with different superscript letters are significantly different $\mathrm{P}<0,01$ )

The high protein of fresh water snail flour which was processed using biological methods was suspected because there are microbial activities in thwas case Lactobacillus sp on the organic material used. The exwastence of these microbes was thought to contribute to protein in fermented feed ingredients. According to Harjo et al (1989) the use of lactic acid bacteria in solid materials in the fermentation process will increase protein around $14-18 \%$ greater than the material before fermentation. Likewwase, Antawidjaja (1997) study of fermented pulp has increased levels of protein and phosphorus. In thwas study, besides aimed at improving the nutrient value of feed ingredients, it was also intended for preservation. The observation of freshwater snail "kalambuai" which was processed by the biological silage method showed a very fast $\mathrm{pH}$ decrease from initial pH 6.7 to 3.8 on day 2 and 3.6 on day 3. According to Harjo et al (1989); Wibowo (1989) low $\mathrm{pH}$ value in the fermentation process will kill pathogenic microorgan and allow the stored feed material to expand. Besides that, along with fermented meat substrate, Lactobacillus was very active to prevent botulwasm, reducing nitrite residues by turning them into nitroust oxide.
In general there was a decrease in the level of coarse crude fiber fresh water snail flour processed by means of acid silage and tepsil compared to steamed freshwater snail. The was happens because in the processing with acid silage decomposition of complex substances becomes simpler. Coarse crude fiber processed by biological silage method tended to be higher especially in P. glauca (4.19\%) as well as phosphorus values where P. glauca phosphorus levels were higher than $1.19 \%$ and $0.14 \%$, respectively. The results of the study are not much different from the research of Antawidjaja (1997) which ferments pulp resulting in a marked increase in phosphorus and crude crude fiber. The high level of crude fiber was due to an increase in dissolved starch levels from rice bran flour during the fermentation process. The results of the study were not much different from Kompiang (1979) study that made silage-snail using cassava seeds. as a source of carbohydrates, the cellulose content increased to $6 \%$ due to an increase in silage starch levels. Likewise on P. Canaliculata there was an increase in crude crude fiber processed with tepsil and steamed methods. It was suspected that steaming and tepsil methods have not been sufficiently able to decompose the crude 


\begin{tabular}{|c|c|c|c|c|}
\hline \multirow{2}{*}{ Species } & \multicolumn{4}{|c|}{ Efficiency of protein use value (\%) } \\
\cline { 2 - 5 } & Steamed & $\begin{array}{c}\text { Silage } \\
\text { acid }\end{array}$ & $\begin{array}{c}\text { Silage } \\
\text { Biologi }\end{array}$ & Tepsil \\
\hline $\begin{array}{c}\text { Pomacea } \\
\text { Glauca }\end{array}$ & $51.104^{\mathrm{d}}$ & $42.241^{\mathrm{c}}$ & $58.258^{\mathrm{f}}$ & $36.282^{\mathrm{a}}$ \\
\hline $\begin{array}{c}\text { Pomacea } \\
\text { Canaliculata }\end{array}$ & $48.850^{\mathrm{d}}$ & $44.461^{\mathrm{c}}$ & $54.418^{\mathrm{e}}$ & $31.208^{\mathrm{a}}$ \\
\hline
\end{tabular}

crude fiber contained in P. Canaliculata which known to contain high crude crude fiber.

\section{B. Efficiency of Protein Use}

The efficiency of using protein was the amount of protein that animals can retain from the amount of protein consumed and used for growth and production. The efficiency of protein use value was determined by the retention of $\mathrm{N}$ obtained by measuring the consumption of $\mathrm{N}$ and excretion of $\mathrm{N}$ in faeces and urine (endogenous $\mathrm{N}$ ) so that it can know the amount of nitrogen left in the body of the animal (Lloyd et al, 1978).

Table 2 showed that P.Glauca species have a better value efficiency of protein use compared to P.Canaliculata species, there is thought to be related to the meat texture of the two species. The results of the observation showed that the texture of the snail meat of the P.Canaliculata species was harder and harder than the species of $P$. glauca. According to Malek (1980) most of the body (mantle) of freshwater and freshwater snail snails was composed of collagen fibrils which are crude fibers.. The body of water snails laughing with P.Canaliculata species contains quite high collagen (Pitojo, 1996). Collagen is the main structural protein in the connective tissue and has a large influence on meat toughness. The higher the collagen content, the more covalent crosslinking was formed. Soeparno (1994) stated that collagen fibrils contain proteins with high molecular weight and are difficult to digest. It was estimated that due to the presence of collagen this causes the efficiency of protein use value in freshwater snail snails to be no more than $50 \%$ with a range of $44,745 \%-46,971 \%$. This figure shows a lower number than laying hens reported by Scott et al (1982) which was $61 \%$. The difference in efficiency of protein use values in addition to the result of differences in the types of livestock also in broilers has been carried out more rigorously and continuously. The highest efficiency of protein use value was obtained in the freshwater snail "kalambuai" which was processed the biological silage method and the lowest value was found in tepsil. the high value of efficiency of protein use on fresh water snail flour, which is processed by biological silage method due to nutrient overhaul, especially protein during the fermentation process takes place. The breakdown of these substances causes protein to be retained more easily. This condition was showed tha by the high nitrogen retention in silage treated with biological methods, namely $\mathrm{N}$ retention in $P$. glauca species $6.04 \%$ and $P$. Canaliculata $5.85 \%$.

\section{TABLE 2. NILAI EFESIENSI PENGGUNAAN PROTEIN TEPUNG KEONG RAWA "KALAMBUAI" DENGAN METODE PENGOLAHAN YANG BERBEDA}
abcd mean value within rows with different superscript letters are significantly different $(\mathrm{P}<0,01)$

In general, freshwater snails processed using biological silage methods have the highest efficiency of protein use values, compared to other treatments, namely $P$. glauca species (58.258\%) and $P$. Canaliculata $(54.418 \%)$. The high efficiency of protein use value was the process of processing in biology. Microbial activity occurs so that the nature of the material in thwas case freshwater snail meat changes due to the breakdown of the nutrients contained in ingredients, one of which was protein. Buckle et al (1987) states that during the process of nutrient change fermentation occur not only by microorganims but, also contained in the ingredients that play a role so that they are more easily digested. In thwas study, snail meat freshwater snail protein, which was processed secretly with a faster method was hydrolyzed into a simpler form and was more easily absorbed by the body to produce better efficiency of protein use values.

Furthermore, the lowest efficiency of protein use values were found in the treatment of snail samples processed using the method, namely P. Canaliculata (31.208\%) and P. glauca $(36.2282 \%)$. Processing with tepsil method uses $3 \%$ formic acid and $2 \%$ salt. The role of formic acid in the process of dwassolving minerals and body twassues from freshwater snails, besides formic acid was bactericidal and was able to preserve. The results of formic acid can lift the mucus found on the surface of bog snail meat. Theoretically, formic acid was not disassociated, because in its form it cannot diffuse into the plasma of bacterial cells. So that the protein breakdown was slower with a decrease in temperature and $\mathrm{pH}$. It was estimated that thwas condition also decreases the efficiency of protein use value. In addition, before being used in cattle, tepsil must be neutralized first by using soda, but thwas research was not neutralized and produced into products that are still very acidic. Acid taste and the role of absence of Alabio ducks,

\section{Protein digestibility}

Processing of freshwater snail meat can significantly increase the value of protein digestibility. Increased digestibility of protein in processed freshwater snails was caused by two things. First, in the processing process, the complex compounds contained in feed ingredients, in this case the protein will break down into simpler forms, namely the form of amino acids and peptides and small amounts of ammonia, so that it will be more easily digested which was then absorbed by the body. According to Finley (1989) heating and acidification in the process of acid silage, biology and tepsil in feed ingredients will cause the protein crystalline structure to be lost, then dwasulfide bonds break down from complex protein tertiary bonds and eventually 
break the helical bonds of proteins so that they are more easily digested. Second, processing will reduce or eliminate the anti-nutrients found in the freshwater snail which was in the form of tannin, which results in tannin being no longer active for protein use. Dharmawati (2003) stated that freshwater snail flour contains tannins of $592 \mathrm{mg} / 100 \mathrm{~g}$ of dry matter. The presence of tannins in fresh freshwater snails flour was likely to play a role in suppressing protein digestibility. According to Benerjee (1982) that tannins have the properties of precipitating proteins and inhibiting the action of enzymes by forming enzyme complexes - tannins. Conversely, processed tannins found in the conch meat can dwassolve. That tannins can dwassolve in hot water or through acidification (Nirtz, 1977). Warming can also break down collagen found in bog snail meat into a soluble and easily digestible protein.

\section{TABLE 3. THE DIGESTIBILITY PROTEIN OF FRESH WATER SNAIL SILAGE WHICH IS PROCESSED BY DIFFERENT METHODS}

\begin{tabular}{|c|c|c|c|c|}
\hline \multirow{2}{*}{ Spesies } & \multicolumn{3}{|c|}{ Protein digestibility (\%) } \\
\cline { 2 - 5 } & Steamed & $\begin{array}{c}\text { Silage } \\
\text { acid }\end{array}$ & $\begin{array}{c}\text { Silage } \\
\text { Biologi }\end{array}$ & Tepsil \\
\hline $\begin{array}{c}\text { Pomacea } \\
\text { Glauca }\end{array}$ & $82.882^{\mathrm{b}}$ & $83.859^{\mathrm{c}}$ & $86.944^{\mathrm{e}}$ & $87.090^{\mathrm{e}}$ \\
\hline $\begin{array}{c}\text { Pomacea } \\
\text { canaliculata }\end{array}$ & $79.148^{\mathrm{a}}$ & $83.606^{\mathrm{c}}$ & $83.901^{\mathrm{c}}$ & $85.149^{\mathrm{d}}$ \\
& \multicolumn{3}{|c}{} & \\
\hline
\end{tabular}

Protein digestibility of both snail species $P$. Glauca and $P$. Canaliculata increased compared to protein digestibility processed by steaming method. Biological silage and tepsil tend to have higher protein digestibility than other treatments (especially in $P$. glauca). The presence of formic acid in tepsil processing was intended to break down the freshwater snail tissue, which causes proteolytic enzymes to actively break down proteins into short peptide groups or amino acids that are easily soluble, because formic acid was used to accelerate the melting of freshwater snail meat.

\section{Metabolizable Energy $(\mathrm{kcal} / \mathrm{kg})$}

The average metabolizable energy of processed "kalambuai" fresh water snails was presented in Table 4. The metabolizable energy values of freshwater snail species P.Glauca showed higher metabolizable energy compared to freshwater snail species P.Canaliculata, this is indicates that P.Glauca species were more efficiently used. The more efficient the snails of $P$. Glauca species because the freshwater snail structure was slightly softer than that of P.Canaliculata.

Based on the processing method, the lowest metabolizable energy value was found in the freshwater snail snail treatment which was processed by steaming method, while the freshwater snail treated with acid, biology and tepil silage methods was not significantly different. These three methods, there was a decomposition of substances that block digestibility such as tannins contained in freshwater snail flour to be lost, so that the components of nutrients contained in snail flour become easily digested. The more components are easily digested, the higher the energy absorbed by the animal's body. In line with the opinion of Mc Donald (1978) and Williams et al., (1990), that digestibility was a factor that influences the metabolizable energy of feed, low digestibility causes a lot of energy lost through faeces. That is shows a close relationship between digestibility and metabolizable energy. The situation was caused by the role of acid in the silage process and tepsil in freshwater snail meat was able to remove tannins as a component that blocks the digestibility of the material also degrades collagen found in the snail meat into gelatin (soluble protein) and amino acids so that it was easier to digest. Whereas the freshwater snails steamed by collagen have not been completely degraded and there was still a tannin content in the freshwater snail so that it has a lower metabolizable energy value than the three other treatments. The results of the analysis of variance showed that there was an interaction between the types of snails and the processing of the metabolizable value of the freshwater snail flour produced. The existence of this interaction means the value of the metabolizable energy of the freshwater snail flour produced was influenced by species factors and processing methods.

Table 4. Metabolizable energy value of fresh water snail silage treated with different methods

\begin{tabular}{|c|c|c|c|c|}
\hline \multirow{2}{*}{ Species } & \multicolumn{4}{|c|}{ Metabolizable energy value (kcal/kg) } \\
\cline { 2 - 5 } & Steamed & $\begin{array}{c}\text { Silage } \\
\text { acid }\end{array}$ & $\begin{array}{c}\text { Silage } \\
\text { Biologi }\end{array}$ & Tepsil \\
\hline $\begin{array}{c}\text { Pomacea } \\
\text { Glauca }\end{array}$ & $2783.02^{\mathrm{a}}$ & $2948.77^{\mathrm{b}}$ & $3076.44^{\mathrm{c}}$ & $2957.72^{\mathrm{b}}$ \\
\hline $\begin{array}{c}\text { Pomacea } \\
\text { canaliculata }\end{array}$ & $2743.99^{\mathrm{a}}$ & $2980.57^{\mathrm{bc}}$ & $2828.44^{\mathrm{a}}$ & $2977.29^{\mathrm{bc}}$ \\
\hline
\end{tabular}

${ }^{\mathrm{abc}}$ mean value within rows with different superscript letters are significantly different $(\mathrm{P}<0,01)$

The metabolizable energy values of freshwater snails of $P$. glauca and $P$. canaliculata species which were processed by steaming methods showed no significant differences but were significantly different from the other three treatments. $P$. glauca and P. Canaliculata which were treated with silage and tepsil increased metabolizable energy compared to steamed ones. The difference was closely related to the nutrient composition of each treatment in addition to the different methods of fresh water snail processing. Wahju (1994) and Amrullah (2003) state that the main factor that causes different metabolizable energy content of feed was due to differences in starch, crude crude fiber, fat and protein content. Based on the results of the interaction, the conch protein content processed by silage and tepsil method 
tends to increase compared to steam ones, while the crude fat and crude fiber values vary.

However, it was very striking that the coarse freshwater snail coarse crude fiber which was processed using the biological silage method was higher than the acid and tepsil silage. High crude fiber in biological silage also contributes to higher metabolizable energy than other treatments. The coarse crude fiber found in freshwater snails were treated biologically silage more easily digested. According to Kompiang (1999) crude fiber in biological silage has the form of starch contributed by carbohydrate sources in thwas study using tapioca. Besides being determined by nutrient composition, the value of metabolizable energy was also determined by the availability of vitamin B complex. Materials that contain vitamin B will have a higher energy content, because vitamin B plays a role in the body's metabolizable function (Amrullah, 2003). Although the content of vitamin B complex was not analyzed in this study estimated that freshwater snails that were processed using biological silage contained a higher $\mathrm{B}$ vitamin complex because of the ability of microbes to synthesize in producing vitamin $\mathrm{B}$ during the fermentation process.

\section{CONCLUSION}

1. The high nutrient content of silage fresh water snails, especially protein content, was obtained from fresh water snails which were processed by biological silage of P.glauca species $(61.64 \%)$ and $P$. canaliculata (57.78\%)

2. The quality of the fresh water snail biology is the best species P. canaliculata and P.glauca obtained in the processing of biological silage method to efficiency protein value of $54.42 \%-58.26 \%$, digestibility protein of $83.90 \%-896.94 \%$.

3. The metabolizable energy value fresh water snail were species $P$. glauca with processed silage biology methods ie $3076.44 \mathrm{kcal} / \mathrm{kg}$.

\section{ACKNOWLEDGMENT}

The autors would like to thank directoratye general of higher education, research and community service department that has provides funding of this research by applied research . I would also like to thank the Faculty of Agriculture, Departement Animal Husbandry, Kalimantan Islamic University of Banjarmasin for allowing and helping me to carry out this laboratory experiment. Thanks also to the laboratory of Basic Laboratory Lambung Mangkurat University Banjarmasin, the IPB Bogor Laboratory and the Bogor Post Harvest Center.

\section{REFERENCES}

[1] Amrullah, I.K. Nutrisi Ayam Broiler. Lembaga Satu Gunungbudi. Bogor, hal : 61-63. 2003.
[2] Antawidjaja, T., Bintang, I.A.K. Supriyati., Sinurat, A.P. dan Kompiang, I.P. Penggunaan Ampas Kirai (Metroxylon Sago) dan Hasil Fermentasinya sebagai Bahan Pakan Itik Yang sedang Tumbuh. Jurnal Ilmu ternak dan Veteriner 2 (3) : 175-180. 1997.

[3] Benerjee, G.C. A. Text Book of Animal Husbandry. Oxford \& I.B.H. Publishing Co, New Delhi. pp. 221-222. 1982.

[4] Buckle, R.A. Edward, R.A. Fleet, G.H. dan Wooton, M. Ilmu Pangan. Universitas Indonesia. Jakarta. (Terjemahan). Hal 92-109. 1990.

[5] Dharmawati, S, Pengaruh Pengolahan Keong Mas terhadap Nilai Energi Metabolis dan Kecernaan Protein Serta Implikasinya pada Ayam Broiler. Hasil Penelitian. Faperta Uniska Banjarmasin. 2004.

[6] Dharmawati, S, Pengaruh Pengolahan Keong Rawa "Kalambuai" terhadap Nilai Energi Metabolis dan Kecernaan Protein Serta Implikasinya pada Ayam Broiler. Hasil Penelitian. Faperta Uniska Banjarmasin. 2006.

[7] Dharmawati, S, Pengaruh Pengolahan Keong Rawa "Kalambuai" dan Penggunaannya pada Itik Alabio Jantan. Hasil Penelitian. Faperta Uniska Banjarmasin. 2006.

[8] Dharmawati S, Firahmi, Khafizah, L. Pengaruh Lama Penyimpanan Silase Keong Rawa yang Menggunakan Onggok terhadap Energi Metabolis dan Daya Cerma Protein. Majalah ilmiah Pertanian Zira'ah, Volume 33 Nomor 1,Pebruari 2012. ISSN Cetak :14121468,. ISSN Elektronik : 2355-3545-4731. 2012.

[9] Finley, J. Philips, R.D., Protein Quality and The Effects of Processing. Marcel Dekker, INC. New York and Basel. pp 1-7. 1989.

[10] Harjo, S., Indrasti, N.S., Bantecut, T. Biokonversi Pemanfaatan Limbah Industri Pertanian. Dirjen Dikti. PAU Pangan dan dan Gizi. IOB. Bogor. Hal 90-103. 1989.

[11] Kompiang. I.P., Supriyadi, A. Suharto dan Purnama. Silase Bekicot (A. Fulica) - Onggok dalam Ransum Starter Ayam Pedaging. Proc. Seminar Penelitian dan Penunjang Pengembangan Peternakan. Jilid2, 9-11. 1999.

[12] Lloyd, L.E. Crampton, E.W, and Mc Donald, B.E. Fundamentals of Nutrition. Second Edition. W.H. Freeman and Company. San Fransisco. pp. 319-333. 1978.

[13] Maynard, A.L., Loosli, K.J., Hinzt, H., and Warner, G.R. Animal Nutrition. Seventh Edition. Mc Graw - Hill Book Company, Philippine. pp. $136-416.1980$.

[14] Mc Donald, P., R.A. Edwards and J.F.O. Greenhalgh. Aninal Nutrition. 3 th Ed. Longman Group Ltd. London - New York. pp. 58. 1978.

[15] Nirtz, M.O. Tannic Acid. The Encyclopedia America. Volume 18. America Co, Inc. pp. $266-267.1977$.

[16] Noviana, Y. Lestari, S. Hanggita, S.RJ. Karakteristik Kimia dan Mikrobiologi Silase Keong Mas (Pomacea canaliculata) dengan Penambahan Asam Formiat dan Bakteri Asam Laktat 3B104. Jurnal Fistech. Volume I Nomor 01. November 2012. 55-67. 2012.

[17] Prashad, B. Anatomy of the Common Apple Snail P. globosa. Memoir of Indian Museum. 1952.

[18] Riani, E. Keong Mas Kaya dengan Protein tapi juga Disebut sebagai Hama Padi. Harian Merdeka, 25 November 1990. 1990.

[19] Riani, E. Beberapa Aspek Keong Murbei (Pomacea sp). Tesis. Program Pascasarjana IPB. Bogor. 1992.

[20] Scott and Dean, Nutrition and Management of Ducks. Published by M.L. Scott of Ithaca. Ithaca. Pp. 58-65. 1991.

[21] Soeparno, Ilmu dan Teknologi Daging. Gadjah Mada University. Hal 28-30. 1994.

[22] Udoh, A.P. E.O. Akpanyung dan I. E. Igiran, Nutrients and Anti Nutrient in Small Snails. Departemen of Chemistry and Biochemistry. University of UYO. Uyo Akwa, Ibon State. Nigeria. pp. 124-125. 1994.

[23] Wahju, J. Ilmu Nutrisi Ternak Unggas. Gadjah Mada University Press. Yogyakarta. Hal : 14-23. 1994.

[24] Wibowo, D. Biokimia Proses Fermentasi. PAU Pangan dan Gizi. UGM. Yogyakarta. Hal : 110-151. 1990.

[25] Williams, G. dan W. J. A. Payne, Pengantar Peternakan di Daerah Tropis. Gadjah Mada University Press. Yogyakarta. 1990. 